\title{
Conversas com um jovem professor
}

\section{Karine Correia dos Santos de Oliveira ${ }^{1}$}

e-mail: karineletras@yahoo.com.br

KARNAL, Leandro (com a colaboração de Rose Karnal). Conversas com um

jovem professor. São Paulo: Contexto, 2012.

O livro Conversas com um jovem professor de Leandro Karnal foi publicado em 2012, pela editora Contexto. É um texto subjetivo sobre práticas anteriores e atuais com o ensino, podendo inspirar professores de diferentes áreas a também se exporem e desabafarem seus dilemas e sucessos com a profissão. Ele se vale de experiências em instituições públicas e privadas, em diferentes níveis de ensino. Dizeres de alunos, professores de diferentes disciplinas e outros agentes da escola podem ser facilmente imaginados e recuperados, com muito humor e sensibilidade. É o que ocorreu no trecho da página 85 , a seguir:

Eu tive um colega que dava aulas de redação e, quando uma aluna perguntou $o$ motivo de ter tirado a nota 7,0 (sete), ele soltou esta pérola: "porque você tem cara de sete". A frase correu como piada entre os professores. Todos concordávamos: a aluna tinha, de fato, cara de sete. Mas não é um critério válido.

Leandro Karnal é graduado em História pela Universidade do Vale do Rio dos Sinos-Unisinos, doutor em História Social, pela Universidade de São PauloUSP, desde 1994, com a tese Formas de representação religiosa no Brasil e no México do Século XVI. Atualmente, é professor do departamento de História da Universidade Estadual de Campinas-Unicamp. O professor orientou e orienta diversas pesquisas e é autor de vários trabalhos. Na contracapa final do livro, destacam-se outras duas publicações pela mesma editora, História na sala de aula e história dos Estados Unidos. O autor também divulga seu trabalho a partir de diversas palestras no site Youtube.

Na obra, o autor dá dicas positivas e negativas sobre a prática de ensino, por meio de uma linguagem metafórica de fácil entendimento e frases curtas.

${ }^{1}$ Doutoranda em Linguística no Programa de Pós-Graduação stricto sensu em Letras da Pontifícia Universidade Católica de Minas Gerais (PUC Minas). Bolsista da Coordenação de Aperfeiçoamento de Pessoal de Nível Superior (Capes), sob orientação da professora doutora Juliana Alves Assis.

Revista Educação Online, n. 19, jun-ago 2015, p. 1-5 
Pode ativar diferentes interpretações sobre a complexa rede de possibilidades de entendimentos sobre o ofício do professor e iluminar ações. $O$ autor adianta que "soluções" efetivas para todos não existem, o que não tira o valor da divulgação e da troca de experiências docentes, a partir das quais somos nós que decidimos entre repetir ou não no dia a dia da profissão.

São oito capítulos com inúmeros subtítulos, sendo que, ao final de cada um deles, há uma breve resenha de um filme sobre diferentes temáticas da educação. Cinco desses filmes são americanos, um chinês, um alemão e outro inglês. Os papéis principais são os seguintes: uma guia turística, uma adolescente, um professor de literatura, um músico professor, um professor, uma professora de artes, uma professora de língua e literatura e, por fim, um engenheiro professor. As datas de lançamento são 1967, 1989, 1995, 2003, 2007, 2008 e dois em 2009. O desenrolar dos acontecimentos possibilita leituras favoráveis e desfavoráveis, tanto do lado da instituição de ensino tradicional, como do professor criativo, que opta pela diversificação em seus métodos de ensino e contribui para alterações significativas na realidade da escola.

No primeiro capítulo, "A aula-introdução ao jogo e suas regras", o professor escreve sobre alguns aspectos da aula, a expectativa de conhecer e trabalhar em uma escola e uma turma nova, além de alguns medos envolvidos nessas ocasiões. A relação entre professor e alunos, em sala de aula, é comparada com o que ocorre entre um salva-vidas e alguém que está se afogando. Nesse mesmo capítulo, o professor distingue e explica "quatro linhas de força" variáveis para "uma boa aula". Menciona a imprevisibilidade da aula e, ao final, considera-a como a própria vida, um jogo com regras específicas.

Karnal, no segundo capítulo, "As pedras da nossa estrada", ilustra cinco erros que um professor deve evitar. O primeiro é o de não saber lidar de maneira adequada com a autoridade e com a avaliação. É possível que provas muito difíceis percam um pouco a função de verificação se a aprendizagem ocorreu ou não. O terceiro é sobre a impaciência com alguns alunos difíceis. Segundo Karnal, "o rosto do professor e sua linguagem corporal indireta são mais observados pelos alunos do que a fala em si" (p. 36). O quarto erro é a competição, que pode gerar

Revista Educação Online, n. 19, jun-ago 2015, p. 1-5 
situações complicadas. Por fim, o quinto erro é o de desistir de um aluno. Ele defende que "O aluno-problema precisa de nós, não o brilhante" (p. 39). São esses que mais desafiam e mais marcam o trabalho docente.

$\mathrm{Na}$ sequência, com o seu terceiro capítulo, Leandro Karnal questiona o ideal de criatividade, que depende das condições de trabalho, da quantidade de turmas, dos alunos e da necessidade de um trabalho específico para a construção de métodos diferentes. Tanto métodos inovadores como aqueles mais tradicionais fazem parte da realidade do trabalho docente. Ele lembra que a memória é ativada com recordações, repetições e também por emoções. Desse modo, a surpresa possibilitada por aulas criativas também é importante para a formação de alunos mais capazes.

O quarto capítulo, "Pais, colegas e diretores", é centrado em conselhos sobre convivência entre vários outros envolvidos na formação dos alunos. Ele atribui diferentes valores a pais, colegas e diretores, no processo de ensino e aprendizagem. Além disso, opina sobre os limites entre o público e o privado na carreira docente. Há um trecho especial, "No magistério, deve se ter cuidado com a genialidade solitária e isolada" (p. 75).

No capítulo quinto, "Apertem os cintos, chegou o dia da prova”, a discussão é centrada na primeira avaliação do ano e em como ela pode afetar o ambiente das aulas, da escola e, principalmente, as relações entre professor e alunos. A verificação de aprendizagem é um momento decisivo para delimitação do aprendido ou não. Ele descreve, em detalhes, as etapas gerais do processo de revisão, desde a elaboração da prova até o conselho de classe. Pensa a avaliação como um documento de cada professor, que deveria poder escolher entre diferentes métodos de aplicação. Porém, em algumas escolas isso não é possível, pois a avaliação deve se encaixar em um método estabelecido previamente ou até representar um grupo de professores de uma área. É o que ocorre, por exemplo, quando a avaliação deve ser sempre aplicada no mesmo dia e horário, por outros professores ou agentes da escola, com limites para questões abertas e fechadas.

No capítulo seguinte, "Tecnologia e sala de aula", o professor retoma algumas concepções pessimistas e otimistas sobre o uso da tecnologia em sala

Revista Educação Online, n. 19, jun-ago 2015, p. 1-5 
de aula. Ele é a favor, desde que isso não seja o foco, tomando todo o espaço da aula. Fugir da tecnologia não é uma opção para a educação atual, porém, deve haver contribuição para uma formação cada vez mais autônoma dos sujeitos envolvidos no processo, e não o contrário.

O penúltimo capítulo, "Disciplina", foi escrito por Rose Karnal, irmã do autor principal e uma professora com mais de trinta anos de carreira nos anos iniciais do ensino fundamental. Ela defende a necessidade de limites entre a atuação do professor e dos alunos e, além disso, "punição", para que os alunos possam aprender cada vez mais com os erros e as consequências. A professora conta que sua paixão pelo ensino começou na infância, com brincadeiras de boneca. Lembra que, em seu estágio na graduação no curso normal, ela foi mal recebida por alunos que não aceitavam a partida da estagiária anterior, muito querida. Mesmo assim, ela não desistiu, e as brincadeiras de criança se tornaram profissão. Além desse acontecimento desafiador, a professora explica que "Inúmeras situações complexas acompanham o cotidiano escolar, desde a falta de materiais, número de alunos por turma, falta de motivação, violência verbal ou física, a indisciplina..." (p. 111).

Para esses e outros problemas da profissão docente, a professora relata uma atitude: "Procuro, ao preparar as aulas da semana, elaborar atividades a mais, para evitar a criação repentina durante os períodos" (p.113). Ao final, há uma lista de fundamentos para que a disciplina impere em sala de aula. $O$ filme indicado é sobre a trajetória de uma professora de língua inglesa e literatura, que busca reduzir os conflitos estabelecidos em uma instituição de ensino com alunos vindos de ambientes muito violentos, assim como o que ocorre na maioria das escolas brasileiras.

No oitavo e último capítulo, "Por que continuo sendo professor?", Leandro Karnal faz um balanço com algumas flores e espinhos da profissão docente. Ele salienta seu gosto por estar entre outras pessoas e por acreditar no poder transformador do conhecimento. Finaliza com linhas motivadoras, "Sou professor porque sou feliz" e "Não houve um único dia nestes 30 anos em que eu não sentisse uma emoção por ser professor" (p. 133).

Revista Educação Online, n. 19, jun-ago 2015, p. 1-5 
O livro Conversas com um jovem professor é um texto leve e com grandes possibilidades de inspirações e orientações para aqueles que são ou se tornarão professores. Ele contribui para quem estiver interessado em conhecer e pensar sobre questões práticas e menos específicas de áreas disciplinares, envolvidas com a educação e o ensino. 